\title{
UMA NOVA HUMANIDADE: O HORIZONTE MESSIÂNICO DE JESUS DE NAZARÉ NO EVANGELHO DE MATEUS
}

\begin{abstract}
A New Humanity: the Messianic Horizon of Jesus of Nazareth in the Gospel of Matthew
\end{abstract}

Jaldemir Vitório *

RESUMO: A epígrafe do Evangelho de Mateus baliza sua catequese. Propõe-se a escrever o "livro da origem de Jesus Cristo" (Mt 1,1), narrar Jesus em sua condição messiânica. Sua identidade vai sendo descrita ao longo da narração, desde a genealogia até o envio dos apóstolos pelo Ressuscitado. O presente texto tem o escopo de verificar o horizonte da ação messiânica de Jesus, ou seja, os objetivos visados. Servindo-se das intuições do método da análise narrativa, a catequese mateana será revisitada, na tentativa de sistematizar os elementos que permitem captar a pretensão do Messias Jesus, no sentido de fazer germinar a nova humanidade, querida pelo Pai dos Céus. E, afinal, esboçar, em grandes linhas, o rosto dessa nova humanidade, expressão do Reinado de Deus e parâmetro para o agir dos discípulos e das discípulas de Jesus de Nazaré, de todos os tempos.

PALAVRAS-CHAVE: Jesus Cristo. Evangelho de Mateus. Messianismo. Exousía. Nova humanidade.

\begin{abstract}
The epigraph of Matthew's Gospel beacons his catechesis. Matthew proposes to write the "book of the origin of Jesus Christ" (Mt 1,1), to narrate Jesus in his messianic condition. His identity is described throughout the narrative, from the genealogy to the commissioning of the apostles after the Resurrection. The present text aims to verify the horizon of Jesus' messianic activity, that is, his pursued objective. By applying the intuitions from the method of narrative analysis, the Matthean catechesis will be revisited, in an attempt to systematize the elements that allow us to capture the purpose of the Messiah Jesus, in order to bring forth the new humanity, desired by the Father in Heavens. And, finally, it sketches out, in broad lines, the
\end{abstract}

* Faculdade Jesuíta de Filosofia e Teologia, Belo Horizonte, Minas Gerais, Brasil. 
face of this new humanity, an expression of the Kingdom of God and a parameter for the action of the disciples of Jesus of Nazareth, at all times.

KEYWORDS: Jesus Christ. Matthew's Gospel. Messianism. Exousía. New Humanity.

\section{Introdução}

Abertura do Evangelho de Mateus, "Livro da origem de Jesus Cristo" I(Mt 1,1), aponta seu propósito de narrar Jesus de Nazaré na condição de "messias" (christós). As expectativas messiânicas do judaísmo do século I faziam-se presentes na comunidade do evangelista, em sua maioria, formada por judeus que aderiram ao movimento de Jesus. Os discípulos eram atraídos pelos ensinamentos e pelo testemunho do Mestre que falava do "Reino de Deus e sua justiça" (Mt 6,33) e lhes descortinava a possibilidade de se criar uma sociedade diferente. Nela todos seriam irmãos (Mt 23,8); o cuidado com os pequenos e os fracos teria relevância (Mt 25,34-40) e o espírito de serviço desarticularia os esquemas mundanos de senhor-servo, grande-pequeno (Mt 20,26-27).

O Messias Jesus não está interessado em se confrontar com o Império Romano, tampouco conquistar o poder em Israel, para relançar o reino davídico, como pretendiam os candidatos a messias. Como um grão de mostarda lançado na terra (Mt 13,31-32), colocou as bases de uma nova humanidade, conformada com a vontade do Pai, a ser praticada "na terra, como no céu" (Mt 6,10). Por isso, pôs-se ao lado dos pequenos, pecadores, marginalizados, estrangeiros, cuja humanidade deveria ser resgatada.

Seu messianismo, "que mais tarde seria chamado de cristologia" (CURVILLIER, 2009, p. 159), assumiu na catequese mateana um viés peculiar, na contramão dos messianismos nacionalistas e liberacionistas. Na condição de "Filho de Davi", pregou o amor aos inimigos (Mt 5,44), recusou toda forma de violência (Mt 26,52) e identificou a presença de uma fé consistente entre os não judeus (Mt 8,5-13; 15,21-28).

Messias sim, mas que implode os messianismos centrados no poder das armas e na dominação, com seus desdobramentos contrários à fraternidade e à justiça. Jesus distanciou-se do protótipo de messias davídico identificado como herói militar e seu projeto de restauração política. O título de rei lhe cabe com o sentido preciso de lugar-tenente de Deus, com a tarefa de fazer o Reino acontecer, como evento de justiça e de shalom para todos (Mt 2,2; 27,11). Por sua vez, o enraizamento na tradição abraâmica, "Filho de Abraão" (Mt 1,1), tornava-o portador de bênção para todos os povos, superando os estreitos limites de Israel.

A tradição judaica comporta uma história do messianismo, com grande variedade de figuras messiânicas, dependendo dos grupos que as cultivavam. Grosso modo, caracterizavam-se por duas grandes tendências: res- 
tauracionista, numa linha davídica, visando a libertação do jugo romano; apocalíptica, contando com a restauração operada por intervenção divina, como fim da história (CARVALHO, 2000, p. 29-51).

Homem do seu tempo, Jesus de Nazaré "comprometido com os conflitos de seus contemporâneos [...] assume todas as aspirações imediatas dos movimentos populares, messiânicos ou não, daquela época" (RIBEIRO, 2009, p. 52).

Jesus nunca se denominou como Messias, embora a sua atividade seja nitidamente messiânica, como demonstram a sua pregação sobre o despontar do Reino de Deus, a cura de doenças e possessão de demônios, ressuscitar mortos e o perdão dos pecados, características do Messias esperado (RIBEIRO, 2009, p. 46).

$\mathrm{O}$ presente estudo centra-se, exclusivamente, na catequese mateana, com o intuito de delinear os traços do messianismo de Jesus de Nazaré, omitindo-se de considerar as pelejas messiânicas do século I (SCARDELAI, 2008, p. 9-22). As intuições oferecidas pelo método da análise narrativa permitirão identificar no conjunto do evangelho, lido intratextualmente, uma preocupação do catequista-narrador: oferecer aos leitores-ouvintes, com clareza e objetividade, o projeto do Messias Jesus, ao qual aderiram com a disposição de torná-lo pauta de ação. Quem se dispõe a segui-lo, deverá estar ciente das implicações de sua decisão (Mt 16,24-25). Trata-se de um Messias diferente que visa a uma nova humanidade, um "povo renovado" (PAGOLA, 2007, p. 64), que entrelace todos os seres humanos pelos vínculos da fraternidade e da misericórdia, presentes na história como sal, luz e fermento, para transformá-la, na força do Espírito Santo.

O primeiro passo mostrará como o evangelista propõe-se a apresentar a identidade messiânica de Jesus de Nazaré, referido como "Jesus Cristo" (item 1). Por não se ter declarado abertamente como Messias, pairavam no ar interrogações a respeito da sua identidade messiânica (item 2). Porém, Jesus mesmo ofereceu pistas para que os interessados tirassem as próprias conclusões (item 3). Uma pista importante estava contida no nome que recebeu por ordem do Anjo (item 4). Seu agir messiânico decorreu da exousía recebida do Pai dos Céus com a qual realizava dynámeis em favor dos desumanizados (item 5). Nas entrelinhas da catequese mateana, as palavras e as ações do Messias Jesus esboçam a humanidade querida pelo Pai, sinal de seu Reinado na história (item 6).

\section{A catequese mateana em chave messiânica}

O messianismo está no frontispício da catequese mateana: "livro da origem (génesis) de Jesus Cristo, Filho de Davi, Filho de Abraão" (Mt 1,1)1.

${ }^{1} \mathrm{O}$ título "Filho de Davi" ocorre 8x no evangelho: Mt 1,1; 9,27; 12,23; 15,22; 20,30, 21,9.15; 22,42. “Em todas as perícopes onde Jesus é identificado como 'Filho de Davi', existe conflito. A atmosfera que envolve o título é totalmente negativa" (JONES, 1994, p. 268). 
Estabelece-se, assim, seu objetivo: mostrar como nasceu o projeto messiânico de Jesus, o Cristo (mashiah), e sua ligação com a tradição davídica e a tradição abraâmica. O conjunto do evangelho explicitará a vertente político-social do ministério do Messias Jesus (dimensão davídica), bem como sua projeção para além de Israel (dimensão abraâmica). Uma vertente significativa, não aludida na abertura, diz respeito à sua condição de profeta (dimensão profética), considerando que "o narrador mateano utiliza, mais que os outros relatos evangélicos, o substantivo profeta e o verbo profetizar, em particular, nas fórmulas de cumprimento" (ALETTI, 2019, p. 74). A identidade messiânica de Jesus será construída com esses três filões hermenêuticos.

A comunidade do evangelista nutria ideais messiânicos com a peculiaridade de centrar a esperança no Messias Jesus. Se, por um lado, o evangelho acolhe esse anseio, por outro, mostra a originalidade do messianismo jesuânico, comparado com outros messianismos. Deixando de lado o enfrentamento com o Império Romano e superando o nacionalismo judaico, o Messias Jesus empenha-se na construção de uma nova humanidade, contando com a ação dos discípulos do Reino. Será tarefa deles levar adiante a obra iniciada pelo Mestre, ao serem enviados a todos os povos e nações, a quem deveriam convidar para se fazerem discípulos (mathetéuo) (Mt 28,19).

O alicerce do Israel universal será a acolhida obediente da vontade do Pai e a criação de laços de fraternidade, alicerçados na solidariedade, na partilha, no perdão e na reconciliação. Tal projeto de sociedade alternativa integra todas as classes sociais, a começar pelos marginalizados e excluídos, pautando-se pelo ethos da misericórdia que inverte as escalas de valores geradoras de desigualdades e hierarquias.

O messianismo davídico, que pensa o Messias como rei, se faz presente em todo o evangelho nas referências ao Reino dos Céus, outra forma de dizer Reino de Deus (VAN EGMOND, 2006, p. 41-71). Por outro lado, o tema da realeza aparece no início e no final do evangelho, um expediente literário chamado inclusão. A genealogia de Jesus, artificialmente elaborada, trabalha com o número quatorze (Mt 1,17) que, na simbologia judaica, correspondia ao nome Davi: $\mathrm{D}=4 ; \mathrm{V}=6$; $\mathrm{D}=4$. Jesus, como se fora um Davi escatológico, tem a missão de fazer acontecer o Reino de Deus definitivo. Os Magos, vindos de longe à procura do "rei dos judeus recém-nascido" (Mt 2,2), alegram-se por encontrá-lo ao verem "o menino com Maria, sua mãe" e lhe oferecem presentes dignos de reis (Mt 2,11-12). Trata-se do novo Davi referido na genealogia!

No final do evangelho, a citação de Zc 9,9 chama a atenção para o messianismo davídico de Jesus, "dizei à Filha de Sião: eis que o teu rei vem a ti"; a multidão clama: "hosana ao Filho de Davi" (Mt 21,4-8). Pilatos interroga-o: "és tu o rei dos judeus?", e recebe uma resposta enigmática: "tu o dizes!" (Mt 27,11). Referindo-se a ele como "o chamado (legómenon) Cristo", a auto- 
ridade romana indica que a condição messiânica de Jesus era reconhecida, mesmo sem dizer que o distinguia como tal (Mt 27,17.22). Os carrascos, quando lhe fazem zombarias: "salve, rei dos judeus!" (Mt 27,28-29), põem em dúvida sua condição real, "[...] se é Rei de Israel, desça agora da cruz e creremos nele!" (Mt 27,42). A placa, "este é Jesus, o Rei dos Judeus" (Mt 27,37), afirma definitivamente sua condição de messias davídico.

O messianismo abraâmico, que pensa o Messias como portador de bênçãos para toda a humanidade (Gn 12,2-3; 15,5), faz-se presente no conjunto do evangelho com a ação humanizadora de Jesus que atualiza a promessa de outrora: "por ti serão abençoados todos os povos da terra". Os apóstolos levarão tal bênção "a todas as nações" (Mt 28,19).

O messianismo profético, que entende o Messias como enviado de Deus, quiçá seja o viés mais presente na catequese mateana. O Messias davídico é um profeta messiânico (VAN EGMOND, 2006, p. 52). O “evangelho da infância" (Mt 1-2) contém cinco citações dos profetas para sublinhar a convergência entre a gênese do Messias e os oráculos dos profetas de Israel (Is 7,14 [Mt 1,23]; Mq 4,1-3 [Mt 2,6]; Os 11,1 [Mt 2,15]; Jr 31,15 [Mt 2,18]; Mt 2,23 [sem correspondência veterotestamentária, apesar de afirmar: "para que se cumprisse o que foi dito pelos profetas"])2. Um provérbio citado por Jesus estabelece o paralelo entre ele e a tradição profética: "não há profeta sem honra, exceto em sua pátria e em sua casa" (Mt 13,57). No entanto, as pessoas consideram-no profeta: "uns afirmam que é João Batista, outros que é Elias, outros, ainda, que é Jeremias ou um dos profetas" (Mt $16,14)$. Esse ponto de vista mantém-se por ocasião da entrada triunfal em Jerusalém: "este é o profeta Jesus, de Nazaré na Galileia" (Mt 21,11). A liderança religiosa temia prendê-lo, "pois as multidões o consideravam profeta" (Mt 21,46). Sua identidade e missão proféticas são evocadas ao se confrontar com a perspectiva de morte violenta: "Jerusalém, Jerusalém, que matas os profetas e apedrejas o que te são enviados" (Mt 23,37). Como profeta, Jesus viveu! Como profeta, haveria de morrer!

\section{A identidade do Messias}

A pergunta dos discípulos de João Batista, falando em nome de seu mestre, subjaz à inteira catequese mateana: "és tu o que há de vir, ou devemos esperar outro?" (Mt 11,3). O Batista, estando na prisão, ouviu falar "a respeito das obras de Cristo" (Mt 11,2). No passado, reconheceu a identidade

\footnotetext{
${ }^{2} \mathrm{O}$ evangelho está permeado de citações de cumprimento dos oráculos proféticos: Mt 3,3; $4,14-16 ; 8,17 ; 12,17-21 ; 13,14-15.35 ; 21,4-5 ; 27,9-10$. Mateus "coloca as fórmulas de cumprimento em lugares estratégicos ao longo de seu Evangelho, deixando clara sua preocupação" (VILJOEN, 2007, p. 320).
} 
messiânica de Jesus, ao dissuadi-lo: "eu tenho necessidade de ser batizado por ti e tu vens a mim?" (Mt 3,14), agora, vê-se assaltado por dúvidas. O Cristo, como falaram os profetas, libertaria os prisioneiros (Is 42,$6 ; 61,1$ ). Como então, estava sendo ainda mantido no cárcere, carecendo do Messias para restabelecer a justiça e libertá-lo (Mt 14,3-12)?

A questão do Batista toca a identidade do Messias. Um ponto em comum, entre os muitos candidatos, consistia em serem "homens fanáticos e idealistas, tanto do ponto de vista religioso, quanto do ponto de vista revolucionário, com amor patriótico, a ponto de pretenderem enfrentar e derrubar o domínio romano" (RIBEIRO, 2009, p. 41). Muitos tentaram desempenhar esse papel, num tempo em que o peso da dominação romana se fazia sentir (At 5,34-39).

Essa tensão messiânica pode ser observada no relato da paixão. Quando Jesus estava sendo aprisionado, "um dos que estavam com ele, estendendo a mão, desembainhou a espada e, ferindo o servo do Sumo Sacerdote, decepou-lhe a orelha". No entanto, foi censurado: "guarda tua espada, pois todos os que pegam a espada pela espada perecerão" (Mt 26,51-52), em conformidade com as bem-aventuranças do Reino (Mt 5,4.7.9). Jesus recusou-se a lançar mão da violência contra quem vinha a seu encontro, "com espadas e paus" (Mt 26,47), mesmo podendo "apelar para meu pai, para que pusesse à minha disposição, mais de doze legiões de anjos" (Mt 26,53). Se lhe cabe o título de Messias, sê-lo-á com a marca da não violência, da misericórdia e da paz, em consonância com o título isaiano "Príncipe da Paz" (Is 9,5), razão por que frustrou "as expectativas populares de um libertador político-messiânico" (VAN EGMOND, 2006, p. 69).

A decisão de vender o Mestre expressa a frustração do ideal messiânico de Judas Iscariotes. No diálogo com o chefe dos sacerdotes, combinou o preço da traição, fixado em "trinta moedas de prata" (Mt 26,15; 27,3), posteriormente, entendido como cumprimento de um oráculo profético (Mt 27,9; Zc 11,12). A confissão, "pequei, entregando sangue inocente" (Mt 27,4), decorre de uma releitura dos fatos, embora não fique claro se, afinal, reconheceu o messianismo do Crucificado. Sua expectativa messiânica, apesar de ser chamado "traidor" já no envio missionário (Mt 10,4), podia se basear na convicção de ser Jesus o messias libertador da dominação romana. Com o passar do tempo, começou a se decepcionar, a ponto de perpetrar uma vingança, entregando-o aos inimigos a troco de dinheiro O ápice do remorso de quem traiu o Mestre "messias" com um beijo (Mt 26,50) acontece com o enforcamento (Mt 27,5), estando os chefes dos sacerdotes e os anciãos pouco interessados em seu drama de consciência (Mt 27,4).

O messianismo de Jesus está presente na pergunta de Pilatos com sua resposta enigmática, seguida de silêncio, não obstante as muitas acusações contra ele (Mt 27,11-14). A interrogação da autoridade romana tem um 
quê de nonsense. Se o vocábulo "rei" é usado no sentido corriqueiro, o representante do poder imperial já deveria ter sido informado e tomado as devidas providências, por colocar em risco a hegemonia romana. $\mathrm{Na}$ verdade, o prepotente Pilatos sabia estar ali um indivíduo totalmente desprovido de importância política e militar, quiçá iludido com a falsa consciência de poder apelar para Deus que enviaria "doze legiões de anjos" para defendê-lo (Mt 26,53).

Quando Jesus responde "tu o dizes!", parece responder positivamente à pergunta da autoridade romana. Contudo, entendendo a palavra "rei" num sentido inteiramente distinto daquele dado pelos acusadores e pelo que, por ventura, Pilatos poderia lhe dar. Que tipo de rei Jesus pretendia ser? Qual seria seu reino, estando para padecer a morte dos malditos de Deus (na concepção judaica) e dos marginais (na concepção romana)? Como entender sua identidade messiânica, num contexto em que tudo fala de fracasso e de solidão? Os carrascos chamam-no de "Cristo" e pedem uma profecia, ridicularizando quem, para eles, era incapaz de profetizar (Mt 26,68). No entanto, "o silêncio de Jesus corresponde ao dos profetas entregues à morte: por isso ele é verdadeiro profeta" (ALETTI, 2019, p. 77).

O letreiro indicando "o motivo de sua condenação" (Mt 27,37) tem a ver com o messianismo de Jesus, visto que proclama sua identidade messiânica e os destinatários de sua missão (Mt 1,21). A proclamação do "centurião e dos que com ele guardavam Jesus", "de fato, este era filho de Deus!" (Mt 27,54), deixa entrever a presença de não-judeus por ocasião da crucifixão. Assim, também não judeus são incluídos no âmbito da realeza de Jesus, doravante "rei de todos os povos". Os indícios permitem aos leitores-ouvintes responderem a questão: "o Crucificado é o Messias, ou temos que esperar outro?

\section{Reconhecimento da identidade messiânica}

A resposta de Jesus à questão levantada por João Batista foge à alternativa sim-não, oferecendo uma pista para o reconhecimento de sua identidade messiânica. O longo imperativo "ide contar a João o que ouvis e vedes: os cegos recuperam a vista, os coxos andam, os leprosos são purificados e os surdos ouvem, os mortos ressuscitam e os pobres são evangelizados" (Mt 11,4-5) comporta uma série de elementos fundamentais para a compreensão da identidade messiânica de Jesus.

3.1 A resposta pressupõe o discernimento das palavras e das ações do Mestre. Quem as acolhe com um coração de discípulo chega a conclusões muito distintas da interpretação dos adversários. Quando Jesus curou um endemoninhado mudo, "a multidão ficou admirada e pôs-se a dizer: 
'nunca se viu coisa semelhante em Israel'" (Mt 9,32). No entanto, os fariseus, adversários ferrenhos e onipresentes, apressaram-se em alegar: "é pelo príncipe dos demônios que ele expulsa demônios" (Mt 9,34). Duas hermenêuticas divergentes do mesmo fato! Por conseguinte, Jesus não parece preocupado com a autoconsciência de sua identidade e sim com a maneira como as pessoas o veem (Mt 16,13-16). Cabia, pois, a João Batista responder a própria pergunta!

3.2 As ações elencadas por Jesus recordam o profetismo de Israel e sua preocupação com a postura dos reis, encarregados de fazer acontecer a sociedade querida por Deus. Isaías anseia pelo dia em que "os surdos ouvirão o que se lê, e os olhos dos cegos, livres da escuridão e das trevas, tornarão a ver. Os pobres terão maior alegria em YHWH, os indigentes da terra se regozijarão no Santo de Israel" (Is 29,18-19). E mais, "se abrirão os olhos dos cegos, e os ouvidos dos surdos se desobstruirão. O coxo saltará como um cervo, e a língua do mudo cantará canções alegres" (Is 35,5-6). Ou, então, "o espírito do Senhor YHWH está sobre mim, porque YHWH me ungiu; enviou-me a anunciar a boa nova aos pobres, a curar os quebrantados de coração e proclamar a liberdade aos cativos, a libertação aos que estão presos, a proclamar um ano aceitável de YHWH e um dia de vingança do nosso Deus, a fim de consolar os enlutados" (Is 61,1-2; Lc 4,16-21). A chave de leitura profética explicita o modo como Jesus quer ser interpretado. Sua existência carregava a marca do profetismo, numa vertente particular: o serviço da reconstrução da humanidade.

3.3 Cada categoria aludida nas palavras de Jesus realça uma dimensão do humano a ser resgatada. Recuperar a visão tem como efeito superar as inúmeras trevas que impedem o ser humano de determinar o rumo de sua caminhada e o desviam do bom caminho. Curar os coxos assinala a importância de o ser humano estar capacitado para colocar todas as suas forças a serviço do bem, totalmente desimpedido para responder aos apelos de Deus. Purificar os leprosos, numa perspectiva bem precisa, aponta para a necessidade de suplantar as causas de desagregação e de marginalização, impedimentos para a comunhão e a fraternidade. Reabilitar a audição desdobra-se na capacitação para a retomada do diálogo, impossibilitado para quem se faz surdo em face do próximo, enclausurando-se em seu mundo pequeno. Ressuscitar os mortos destaca as muitas formas de passagem da morte para a vida, mormente em termos éticos. Anunciar a boa notícia aos pobres fecha o ciclo de ilustrações da humanidade em processo de refazimento. Trata-se de conscientizá-los de seu valor aos olhos de Deus (Mt 5,3).

3.4 $\mathrm{O}$ messianismo de Jesus passa à margem das práticas propriamente religiosas, talvez pela consciência do perigo representado pela religião desumanizadora praticada pelas falsas lideranças religiosas. Seu olhar crítico desses grupos perpassa a catequese mateana (Mt 6,1-18). A preocupação 
em enviar "operários para a messe" (Mt 9,38) relaciona-se com o estado de abandono do povo, "como ovelhas sem pastor" (Mt 9,36), causado por uma religião incapaz de se compadecer de quem não se encaixa em seus rígidos padrões. O Messias estabelece nítida distinção entre dois tipos de religião: a libertadora e a opressora, a humanizadora e a desumanizadora, a interessada no ser humano e a obcecada pela Lei (Mt 11,28-30). Sua ação focava os pecadores e não os justos (Mt 9,13b), visto lhe interessar o resgate da humanidade deteriorada pela ação perniciosa da religião deturpada. Seus conflitos com a elite religiosa atingem o ápice com a denúncia implacável da hipocrisia dos que "amarram fardos pesados e os põem sobre os ombros dos outros, mas eles mesmos nem com um dedo se dispõem a movê-los" (Mt 23,5). O embate com a religião que "mata os profetas e apedreja os que lhe são enviados" (Mt 23,37), tema transversal na catequese mateana, revela um traço da identidade messiânica de Jesus, toda centrada no querer original do Pai (Mt 5,17). A dupla citação de Os 6,6: "misericórdia quero, e não sacrifício" (Mt 9,13a; 12,7) resume o sentido de seu ministério.

\section{Um nome - uma missão}

O nome de Jesus engloba sua missão. Três elementos se destacam no imperativo "tu o chamarás com o nome de Jesus, pois salvará o seu povo de seus pecados" (Mt 1,20-21).

4.1 A palavra grega Iesoús transcreve o hebraico yeshua, mais tarde, yoshua, abreviação de yehoshua, "YHWH é salvação". Um nome carregado de simbolismo! A fé de Israel construiu-se em torno da imagem do Deus salvador, fundamento de toda a teologia bíblica. O marco zero da relação YHWH-Israel foi a libertação dos israelitas oprimidos pelo faraó. "Eu vi, eu vi a miséria do meu povo que está no Egito. Ouvi seu grito por causa dos seus opressores; pois eu conheço as suas angústias" (Ex 3,7) constata YHWH ao enviar Moisés com a missão de libertador: "vai, pois, e eu te enviarei a faraó, para fazer sair do Egito o meu povo, os israelitas" (Ex 3,10).

Tudo começa com uma situação de desumanidade, com os pequenos oprimidos pelos grandes. YHWH assume as dores dos humilhados e decide libertá-los das mãos de quem lhes impõe uma dura servidão, dando-lhes uma terra onde poderão viver a fraternidade, "uma terra boa e vasta, terra que mana leite e mel" (Ex 3,8). O nome Jesus está relacionado com esse núcleo histórico-teológico de Israel!

4.2 A missão do Messias Jesus dizia respeito ao Israel de seu tempo, com o desafio de "ver" a realidade de opressão sofrida por seu povo. O Império Romano se impusera como poder hegemônico sobre todos os povos. Seu 
peso fazia-se sentir no pagamento de impostos, na repressão violenta a qualquer tentativa de libertação e no desrespeito aos valores sagrados da religião de Israel.

O violento Herodes, referido por ocasião da visita dos magos ao "rei dos judeus, recém-nascido" (Mt 2,2), ilustra o horizonte romano da época. A ordem de eliminar "em Belém e em todo seu território, todos os meninos de dois anos para baixo" (Mt 2,16), para se vingar dos magos, serve de amostra para o cotidiano dos judeus subjugados. Herodes Antipas, filho do anterior, mandou decapitar João Batista, por instigação da cunhada tomada como esposa, fato corajosamente denunciado por ele (Mt 14,1-12). Jesus foi condenado à morte por Pilatos. Esse se deixou levar pela truculência dos chefes dos sacerdotes e dos anciãos, que atiçavam as multidões (Mt 27,11-26), apesar da intervenção de sua esposa que declarou a inocência de Jesus, no momento em que era julgado.

A religião estava nas mãos das famílias sacerdotais de Jerusalém, que se apropriaram do Templo e, ávidas de lucro, transformaram-no em "covil de ladrões" (Mt 21,13). As sinagogas eram controladas pelos escribas. Muitos deles, em conluio com os fariseus, impunham ao povo uma religião feita de exterioridade. Quando davam esmolas, trombeteavam "nas sinagogas e nas ruas, com o propósito de serem glorificados pelos homens" (Mt 6,2). Quando rezavam, "faziam oração pondo-se em pé nas sinagogas e nas esquinas, para serem vistos pelos homens" (Mt 6,5). Quando jejuavam, "tomavam um ar sombrio" e "desfiguravam seu rosto para que seu jejum fosse percebido pelos homens" (Mt 6,16).

A principal vítima da opressão político-religiosa era o povo simples. Por isso, o olhar de Jesus voltava-se para quem, como os israelitas no Egito, careciam de um libertador, que, como um novo Moisés, os conduzisse à terra da fraternidade.

4.3 A missão de Jesus consistiu em "salvar o seu povo de seus pecados" (Mt 1,21). A semântica evangélica de pecado nada tem a ver com moralismo, tampouco significa ofensa a Deus. Seu forte é a desumanização! No evangelho, a palavra pecado (hamartía) ocorre 7x, o verbo pecar (hamartáno), $3 \mathrm{x}$, e o adjetivo pecador (hamartolós), $5 \mathrm{x}$.

Além de Mt 1,21, hamartía aparece na confissão dos pecados de quem busca o batismo de João (Mt 3,6). A presença de muitos fariseus e saduceus irrita o Batista, que os chama de "raça de víboras", tentando fugir da ira iminente (Mt 3,7-9). Em Mt 9,2.5.6, a cura do paralítico começa com as palavras: "os teus pecados te são perdoados", e se concretiza com a ordem: "levanta-te, toma tua cama e vai para casa!" A restituição da mobilidade reintegra-o na vida social. Mt 12,31 refere-se à blasfêmia contra o Espírito Santo com o sentido de "pecado contra o Espírito Santo". Entendido como desumanização, coincide com a decisão de se fechar à ação humanizadora 
do Espírito Santo e se enclausurar no egoísmo, tornando-se cego às necessidades do próximo. Por fim, hamartía é usado em Mt 26,28, na última ceia: "isto é o meu sangue, o sangue da Aliança, derramado por muitos para remissão dos pecados". A última menção liga-se à primeira e reforça que toda a vida de Jesus foi um serviço à humanização de seu povo, consumado com a morte de cruz.

O verbo pecar (hamartáno) está presente no discurso eclesial (Mt 18), quando se fala da correção fraterna: "se o teu irmão pecar, vai corrigi-lo a sós" (Mt 18,15). O pecado no âmbito da comunidade do Reino relaciona-se com o egoísmo, a falta de solidariedade e de cuidado com o outro, o desprezo das regras da boa-convivência, enfim, as posturas contrárias à fraternidade. São expressões da desumanidade de quem aderiu ao Reino, sem se deixar humanizar por ele (Mt 7,21-23; 25,31-46). A questão levantada por Pedro, em Mt 18,21, "Senhor, quantas vezes devo perdoar o irmão que pecar contra mim? Até sete vezes?", liga-se ao episódio anterior (Mt 18,15-20). A resposta do Mestre deve ser entendida com o pano de fundo do processo de humanização (Mt 18,22). O discípulo do Reino pode se mostrar inconstante na caminhada, alternando momentos de fraternidade com recaídas no egoísmo. Todavia, sempre que se converter ao amor humanizador, deverá ser perdoado. A última ocorrência de hamartáno em Mateus encontra-se em 27,4, na boca de Judas Iscariotes, que reconhece: "pequei, entregando sangue inocente!" O discípulo traidor revela as dimensões da maldade cometida contra Jesus de Nazaré, o inocente. Seu pecado consistiu em ser desumano com quem o considerava "amigo" (Mt 26,50).

O adjetivo substantivado hamartolós, pecador, ocorre, algumas vezes, em Mt. Aparece quando se fala de Jesus rodeado de "muitos publicanos e pecadores" assentados à mesa com ele e seus discípulos (Mt 9,10). A cena leva os fariseus a perguntarem: "por que o vosso Mestre come com os publicanos e os pecadores?" (Mt 9,11). Recebem como resposta: "eu não vim chamar justos, mas pecadores" (Mt 9,13). Pecadores são os rejeitados pelos fariseus (justos) e sua religião feita de leis e tradições. A presença de Jesus junto deles segue a direção oposta. Quem era chamado de pecador, recebe a acolhida compassiva do Salvador (Mt 1,21) que lhes mostra uma via de humanização e recuperação da dignidade, por serem também filhos do "Pai-nosso" (Mt 6,9)33. Jesus, também, foi vítima dos falsos religiosos que o consideravam "um glutão e beberrão, amigo de publicanos e pecadores" (Mt 11,19). A missão de salvador exigia dele uma postura firme para manter o foco naqueles para quem foi enviado. Finalmente, o termo hamartolós faz-se presente no contexto da paixão, quando os discípulos são alertados: "eis que a hora está chegando e

\footnotetext{
3 "Era característica da comunidade mateana não ter alguém com autoridade oficial para advertir ou expulsar pecadores" (LUZ, 1998, p. 105).
} 
o Filho do Homem está sendo entregue às mãos dos pecadores" (Mt 26,45). Nessa circunstância, quem seriam os pecadores, senão "Judas, um dos Doze, acompanhado de grande multidão com espadas e paus, da parte dos chefes dos sacerdotes e dos anciãos do povo" (Mt 26,47)? Na sequência, são narrados os horrores perpetrados contra Jesus, o justo reconhecido pela esposa de Pilatos (Mt 27,19), o inocente reconhecido pelo traidor (Mt 27,4), o Filho de Deus confessado pelo centurião e os soldados que guardavam o túmulo (Mt 27,54; cf. 27,62-66). Em suma, desde o seu nascimento, a existência de Jesus voltou-se para a salvação da humanidade desfigurada pelo egoísmo e foi toda dedicada aos pecadores carentes de humanização salvadora!

\section{Exousía e dýnamis humanizadoras}

Intrigada com as ações de Jesus, a liderança religiosa queria saber: "com que autoridade (exousía) fazes estas coisas? E quem te concedeu essa autoridade (exousía)?" (Mt 21,23). A palavra "autoridade", no sentido comum, não traduz o vocábulo evangélico. Exousía diz respeito à capacidade de fazer o bem, que escapa da normalidade; uma força que alguém traz consigo e, ao partilhá-la, torna-se fonte de vida e de renovação. Os possuidores desse dom sentem-se impelidos a colocá-lo a serviço do próximo, de modo especial, os mais fragilizados e carentes, os principais beneficiários. Não sabendo como explicá-lo, atribuem-lhe uma origem divina.

Os adversários estavam convencidos de que a exousía de Jesus não provinha de Deus. Talvez, lhes faltasse a coragem de reconhecê-lo, daí atribuíam-na a Beelzebu, chefe dos demônios (Mt 12,24). Jesus refutava-os, veementemente, convicto de ser movido "pelo Espírito de Deus" (Mt 12,25-28). Embora sempre fizesse o bem com a exousía recebida do Pai, não lhe surpreendia ser mal interpretado (Mt 10,25). Sendo assim, se recusava a revelar aos inimigos sua origem (Mt 21,27).

O Messias Jesus tem consciência de ter-lhe sido dada "toda exousía no céu e sobre a terra" (Mt 28,18). O passivo teológico destaca ser Deus sua fonte. O pronome indefinido "toda" (pás) enfatiza as dimensões da exousía de Jesus, que engloba todas as situações onde sua presença salvadora se faz necessária. Eis porque curou "toda e qualquer doença ou enfermidade do povo", pois "traziam-lhe todos os que eram acometidos por doenças diversas e atormentados por enfermidades, bem como endemoninhados, lunáticos e paralíticos, e ele os curava" (Mt 4,23-24; 8,16; 14,35-36; 15,2931. A expressão "no céu e sobre a terra" frisa a abrangência geográfica do seu ministério. Ele "percorria toda a Galileia" (Mt 4,23), "todas as cidades e povoados" (Mt 9,35), primórdios da missão destinada "a todas as nações" (Mt 28,19). 
A exousía do Messias Jesus manifestava-se em duas vertentes. Estava na origem de seus ensinamentos, que extasiavam as multidões, "pois as ensinava com exousía e não como os seus escribas" (Mt 7,28-29). Suas palavras tinham a força de salvar do pecado, ao tocar os corações dos convidados à conversão (Mt 4,17). Converter-se significava abraçar a vontade do Pai e se deixar guiar por ela, como caminho de humanização.

A exousía estava, também, presente em suas ações, a ponto de maravilhar as multidões e levá-las a "glorificar a Deus, que deu tal exousía aos homens" (Mt 9,6.8). O diferencial tornava-se perceptível para quem o acolhia de coração aberto, disposto a compreender suas ações numa perspectiva teológica, ao intuir Deus agindo por seu intermédio. Enquanto os adversários queriam encontrar nele algo de censurável e tendiam a atribuir o bem que fazia às potências demoníacas, quem carecia de "salvação" reconhecia a origem divina de sua exousía.

A exousía recebida do Pai foi partilhada com os discípulos enviados em missão. Os Doze receberam do Mestre "exousía de expulsar os espíritos impuros e de curar toda sorte de males e enfermidades" (Mt 10,1), tendo-lhes sido ordenado: "curai os doentes, ressuscitai os mortos, purificai os leprosos, expulsai os demônios" (Mt 10,7-8). Essa exousía inesgotável seria derramada sobre todos os povos com seu poder de reconstrução da dignidade de cada ser humano vítima da doença, da morte, da exclusão social e da opressão dos espíritos malignos.

O termo dýnamis, traduzido impropriamente por "milagre", relaciona-se com exousía na catequese mateana, por se tratar de seus efeitos na vida das pessoas $^{4}$. A exousía capacitava Jesus para realizar dynámeis, como atualização da "dýnamis de Deus" (Mt 22,29). A dýnamis, no que lhe toca, expressava a exousía concedida pelo Pai ao Filho amado (Mt 4,17; 17,5). Suas dynámeis nem sempre foram bem acolhidas. Corazin, Betsaida e Cafarnaum, "onde havia feito a maior parte de suas dynámeis", não se converteram (metanoéo; Mt 11,21). Jesus as compara com as cidades paradigmas de corrupção e maldade: Tiro, Sidônia e Sodoma. Se essas tivessem sido agraciadas com suas dynámeis, com certeza, "ter-se-iam arrependido, vestindo-se de cilício e se cobrindo de cinza" (Mt 11,20-24).

Experiência semelhante fez o Messias Jesus em Nazaré, sua terra (patrís). Seus conterrâneos se perguntavam: "de onde lhe vêm essa sophía e essas dynámeis?", por reconhecerem haver algo de especial nas dynámeis que realizava. Porém, o preconceito impedia-os de atribuir-lhe uma exousía de origem divina e os levava a se "escandalizarem dele". Resultado: "não fez ali muitas dynámeis, por causa da incredulidade (apistía) deles" (Mt 13,53-58).

${ }^{4}$ As narrativas de milagres têm função messiânica na catequese mateana (PASALA, 2009, p. 411-413). 
As dynámeis de Jesus confundem Herodes, que suspeita tratar-se de João Batista, "ressuscitado dos mortos", ao qual mandara decapitar (Mt 14,1-2). O tirano explicava "as dynámeis em ação (energéo) nele" por um caminho enviesado, pois não se dispunha a abandonar a impiedade, em outras palavras, deixar-se humanizar!

Um texto enigmático na catequese mateana alude à possibilidade de as dynámeis carecerem de exousía. Por ocasião do juízo escatológico, "aquele dia" (Mt 25,31-46), muitos dirão: "Senhor, Senhor, não foi em teu nome que profetizamos e em teu nome expulsamos demônios e em teu nome fizemos muitas dynámeis?" E terão como resposta: "nunca vos conheci. Apartai-vos de mim, praticantes de iniquidade (anomía)" (Mt 7,21-23). A anomía poderia consistir na tentação de realizar dynámeis sem o sentido de recuperar a humanidade dos beneficiados. Quiçá os discípulos desiludidos buscassem autopromoção ou benefícios pessoais com suas dynámeis. Agiam na contramão do Mestre que não caiu na cilada do tentador, ao recusar-se a usar a exousía recebida do Pai para fazer dynámeis em benefício próprio, pois se destinava ao serviço da humanização dos irmãos e irmãs desumanizados (Mt 4,1-4), à "nova criação do povo de Deus que ora acontece", onde "já se mostra uma parcela do novo céu e da nova terra" (LOHFINK, 2015, p. 200).

\section{Rostos da nova humanidade}

As entrelinhas da catequese mateana escondem o rosto da humanidade querida pelo Messias Jesus. A leitura atenta do conjunto permite esboçar, em grandes linhas, o norte de sua ação humanizadora. Diferentemente dos escribas e sua insistência na fidelidade às minúcias da Lei mosaica (Mt 23,23), tomou outro rumo que se pode chamar "lógica do excesso", focada em Deus e no próximo, "uma forma radical de messianismo judaico" (CUVILLIER, 2009, p. 159). Por sua vez, o empenho dos discípulos em radicalizar seu modo de proceder, designado como justiça (dikaiosýne), exigia que se guiassem pelas pautas estabelecidas pelo Mestre (Mt 5,20).

\section{1 "Só ao Senhor teu Deus adorarás e prestarás culto" (Mt 4,10)}

Na base da vida inspirada na sabedoria do Reino está uma opção fundamental: "não podeis servir a Deus ao Dinheiro (mamonás)" (Mt 6,24) A adoração ao Deus verdadeiro exclui todo tipo de idolatria, onde as

\footnotetext{
5 “O termo aramaico mammón (da raiz ' $m n$ ) significa 'o que está seguro' ou 'o que dá segurança"' (PAGOLA, 2007, p. 29).
} 
criaturas assumem o status de divindade. A recusa de adorar as criaturas exige que o ser humano se volte inteiramente para Deus, cujo querer não se encerra em leis religiosas, tampouco pode se expressar em dogmas e doutrinas. Antes, requer o esforço diuturno de optar pelo que humaniza, gera vida e protege a dignidade dos pequenos e dos fracos, pois "não é da vontade (thélema) do vosso Pai que está nos céus, que um destes pequeninos se perca" (Mt 18,14).

O horizonte da ação do Messias Jesus foi o querer divino, como exigência de humanização. A impossibilidade de formalizá-lo com afirmações precisas levou os adversários a pensarem que tivesse a intenção de "revogar a Lei ou os Profetas", ou seja, toda a tradição religiosa de Israel. A declaração "não vim revogá-los, mas dar-lhes pleno cumprimento" (Mt 5,17) deve ser bem entendida. O verbo pleróo, traduzido como "dar cumprimento", tem o sentido de plenificar, fazer acontecer de maneira integral, atingir seu núcleo mais profundo. No caso, "o plano de Deus previamente anunciado atingiu, em Jesus, sua plena conclusão" (VILJOEN, 2007, p. 304), na medida em que "realiza a esperança de Israel, dando à lei e às promessas dos profetas seu real significado" (CUVILLIER, 2009, p. 149). Assim, a afirmação de Jesus revela sua disposição de superar a materialidade da Lei mosaica para alcançar a vontade (thélema) do Pai, à qual se submetia com o objetivo de formar uma nova humanidade (Mt 12,50; VITÓRIO, 2020, 30-38).

A decisão de fazer a "vontade do Pai" determinou o rumo de sua caminhada. Na agonia do Getsêmani, confrontado com a perspectiva de um fim terrível, confessa a disposição de pagar o preço da fidelidade ao querer do Pai: "meu Pai, se não é possível que esta taça passe sem que eu a beba, seja feita a tua vontade" (Mt 26,42). Quando ensina os discípulos a rezarem "seja feita a tua vontade na terra, como no céu" (Mt 6,10), incentiva-os a tomá-la como ponto de referência. Tudo na vida do discípulo do Reino deve se enquadrar no querer do Pai dos Céus, tomado com o imperativo, como fazia o Mestre.

O Messias Jesus violava sistematicamente o preceito do repouso sabático quando se defrontava com um ser humano carente de ajuda, com a justificativa de que "o Filho do Homem é senhor do sábado" (Mt 12,8), no sentido que, sendo preciso fazer o bem, a lei do repouso sabático ficará em segundo lugar. Uma metáfora ilustrava seu proceder. Quando uma ovelha cai num buraco, mesmo sendo sábado, o proprietário se apressa em retirá-la. Já que "um ser humano vale muito mais do que uma ovelha, é lícito fazer o bem aos sábados", sem contrariar a vontade de Deus (Mt 12,11-12). Esse modo de agir irritava os adversários que o espreitavam, determinados a eliminá-lo (Mt 12,14).

Dos discípulos espera submissão à vontade do Pai dos Céus, para além do palavreado vazio. “Nem todo aquele que me diz: 'Senhor, Senhor' entrará 
no Reino dos Céus, mas sim aquele que pratica a vontade (thélema) de meu Pai que está nos céus" (Mt 7,21) reforça a exigência diuturna de adequar cada palavra e cada ação ao querer divino, dando-lhes transcendência. Qualquer outra vontade, inclusive a pessoal, fica em segundo plano, no confronto com o querer do Pai dos Céus que consiste em praticar "a justiça, a misericórdia e a fidelidade" no trato com o semelhante, caminho de humanização (Mt 23,23).

\section{2 "Todos vós sois irmãos!" (Mt 23,8)}

A busca da "justiça" (dikaiosýne), ethos do Reino, superior à dos escribas e à dos fariseus (Mt 5,20), supõe que os discípulos deem um passo além das relações hierárquicas que os divide em mestre e discípulo, pai e filho, líderes e liderados A fraternidade decorre de todos terem um só Mestre, um só Pai, o celeste, e um só guia, o Cristo. Jesus formulou o princípio da fraternidade de maneira lapidar: “todos vós sois irmãos!” (Mt 23,8-12). Esse será o distintivo da humanidade querida pelo Messias Jesus (DÍAZ MATEOS, 2005, p. 79-90).

O Mestre coibiu prontamente a tentação de estabelecer relações assimétricas na comunidade dos discípulos (Mt 18,1-4). A preocupação por saber "quem é o maior no Reino dos Céus" escondia a intenção de identificar o preferido, o superior aos demais. O chamado a se converter e se tornar como as crianças para ser "o maior no Reino dos céus" torna-se metáfora de uma atitude, ao se voltar para uma etapa da vida na qual a luta pela supremacia está fora de cogitação.

A fraternidade, decorrente da paternidade divina e a consequente filiação, serve de horizonte para a oração do Pai-nosso (Mt 6,9-13). A comunidade orante pede, para todos, a vinda do Reino, a obediência à vontade do Pai, o pão cotidiano, o perdão das dívidas, o afastamento do Maligno. Ninguém pede nada para si! $\mathrm{O}$ espírito de fraternidade move os irmãos e as irmãs a se dirigirem ao Pai que conhece suas necessidades (Mt 6,32). Essa comunhão possibilita o evento do shalom bíblico que se torna realidade quando todos se lançam na busca prioritária do "Reino de Deus e sua justiça" (Mt 6,33).

A convivência de Jesus com "muitos publicanos e pecadores", com quem "se assentava à mesa" (Mt 9,10), “comia e bebia" (Mt 11,19), pode ser entendida como esforço para se colocar em pé de igualdade, para resgatá-los pelo viés da misericórdia. Essa pedagogia da proximidade acontece por ocasião do batismo ao entrar na fila dos pecadores que buscavam purificação, com os quais se solidariza (Mt 3,13-14). Trata-se do pastor à procura da ovelha extraviada (Mt 18,12-14) e do irmão excluído da comunidade e tratado "como o gentio ou o publicano" (Mt 18,17). Na perspectiva de Lc 15,11-32, seria o caso do filho mais velho indo atrás do irmão desencami- 
nhado, para trazê-lo de volta à casa paterna, apelando para a misericórdia e a acolhida. Fazendo-se "irmão" dos pecadores, Jesus convida-os a se integrarem na grande família do Pai (Mt 9,12-13).

\section{3 "Todos comeram e ficaram saciados" (Mt 14,20)}

O duplo relato da multiplicação dos pães (Mt 14,13-21; 15,32-39) contém um dado relevante no modo de proceder da humanidade almejada pelo Messias Jesus: a partilha solidária, postura indispensável na vida do discípulo, decorrente da opção pelo Reino e seus desdobramentos (VITÓRIO, 2019, p. 171.183).

O contexto de deserto (Mt 14,15), onde se encontravam multidões, com seus doentes, cria um ambiente dramático e gera apreensão nos discípulos, conscientes da necessidade de se alimentarem, quando percebem que "a hora já está avançada". Então, sugerem ao Mestre despedir as multidões para que elas, pela própria iniciativa, providenciem alimento. O pragmatismo da sugestão olvida aspectos relevantes: as multidões estão longe dos povoados; dificilmente encontrariam lugares para comprar alimentos, por já ser tarde; embora encontrassem, com certeza, faltaria estoque para atender aquele número imenso de gente; os idosos e pessoas com dificuldade de locomoção estariam em desvantagem; por fim, quem não tivesse dinheiro, passaria fome. A sugestão dos discípulos mostrava-se impraticável!

A ordem do Mestre soa-lhes absurda: "não é preciso que vão embora. Dailhes vós mesmos de comer!" Como cumpri-la se têm à disposição apenas "cinco pães e dois peixes"? O dono daquela pequena ração, suficiente para pouquíssimas pessoas, fica no anonimato (Mt 14,17). O milagre da solidariedade e da partilha tem início quando os "cinco pães e os dois peixes" são entregues ao Mestre. Tendo ordenado que "as multidões se acomodassem na grama", faz o gesto a ser repetido por ocasião da ceia pascal (Mt 26,26). Então, "partindo os pães, deu-os aos discípulos, e os discípulos às multidões". Cada qual, ao receber sua porção, deve pensar nos irmãos ao redor e, vencendo a tentação do egoísmo, repartir do pouco que recebeu. Resultado: "todos comeram e ficaram saciados, e ainda recolheram doze cestos cheios dos pedaços que sobraram", apesar de serem "cerca de cinco mil homens, sem contar mulheres e crianças". Passando por alto os vários simbolismos da narração, a mensagem veiculada, no tocante à humanidade ansiada por Jesus, apresenta a solidariedade e a partilha como ponto de partida para a solução dos grandes problemas. Porém, partilha do pouco feita por quem conserva a capacidade de solidarizar-se com o semelhante em suas necessidades.

O segundo relato, Mt 15,32-39, comporta idêntica mensagem, com algumas peculiaridades. Jesus sente profunda compaixão pela multidão que o acompanha há três dias. Não tendo o que comer, reconhece ser inconveniente 
"despedi-la em jejum, por receio de que desfalecesse pelo caminho". Os discípulos explicitam o impasse: "de onde tiraríamos, num deserto, tantos pães para saciar tal multidão?" O Mestre informa-se da quantidade de pães disponível: "sete e poucos peixinhos", porção irrisória para tanta gente. Estando a multidão sentada pelo chão, repete o gesto de dar graças, parti-los e distribui-los entre os discípulos para que os distribuíssem à multidão. Novamente, "todos comeram e ficaram saciados e ainda recolheram sete cestos cheios dos pedaços que sobraram". Detalhe: "os que comeram eram quatro mil homens, sem contar mulheres e crianças". A solidariedade e a partilha, de novo, possibilitaram matar a fome da multidão.

\section{4 "Entre vós não será assim" (Mt 20,26)}

A catequese mateana propõe uma guinada nas relações interpessoais, para que a sociedade se adeque ao "Reino de Deus e sua justiça". O pedido de uma mãe serve de ocasião para o ensinamento de Jesus. Num gesto de adoração (proskynéo), a mãe dos filhos de Zebedeu pede-lhe para conceder a seus filhos "assentar-se um à tua direita e o outro à tua esquerda, no teu Reino" (Mt 20,20-24). Os demais discípulos ficam indignados (Mt 20,24). Qual seria o verdadeiro motivo da revolta?

O Mestre aproveita a oportunidade para ensinar um tópico imprescindível no discipulado do Reino. As relações entre os discípulos deveriam seguir na contramão dos governantes e dos grandes deste mundo, dominadores e tiranos. Pelo contrário, "quem quiser tornar-se grande entre vós seja aquele que serve, e o que quiser ser o primeiro dentre vós, seja o vosso servo", nos passos do Filho do Homem que "não veio para ser servido, mas para servir e dar sua vida como resgate por muitos" (Mt 20,26-28).

Idêntica advertência repete-se no contexto da denúncia da hipocrisia dos escribas e fariseus exibicionistas e sua mania de grandeza. O Mestre ensina: "o maior dentre vós será aquele que vos serve. Aquele que se exaltar será humilhado, e aquele que se humilhar será exaltado" (Mt 23,11-12). O próximo com suas carências determina as relações interpessoais. Quem não tem o espírito de serviço, será tentado a se considerar superior aos demais, e, desse modo, humilhá-los e explorá-los sem compaixão.

A sabedoria do Reino serve de antídoto para eliminar pela raiz a tentação da tirania, do despotismo, da ditadura, do totalitarismo e do absolutismo que acometem as pessoas, dando-lhes o direito de submeter o próximo a seus caprichos.

\section{5 "Mulher, grande é tua fé" (Mt 15,28)}

Traço da humanidade plasmada pelos valores do Reino é a superação da marginalização e da exclusão, muito presentes nas sociedades classistas 
e elitistas. O Messias Jesus age na contramão dessa tendência ao inserir sociorreligiosamente quem vivia nas margens. Entre esses, os doentes (Mt 20,29-34), as crianças (Mt 19,13-15), os estrangeiros (Mt 15,21-28), os pecadores (Mt 9,10-13), o povo simples (Mt 4,24-25) e, de modo especial, as mulheres, que ocupam grande espaço na catequese mateana (VITÓRIO, 1997, p. 353-359).

A genealogia (Mt 1,1-17) supera a tradição patrilinear ao incluir cinco mulheres na génesis de Jesus Cristo: Tamar (Mt 1,3a), Raab (Mt 1,5a), Rute (Mt 1,5b), "aquela que foi mulher de Urias" (Mt 1,6b) e Maria, "da qual nasceu Jesus chamado Cristo" (Mt 1,16). Maria põe fim à genealogia; doravante, a consanguinidade cede lugar a outro tipo de vinculação com o Messias: "aquele que fizer a vontade de meu Pai que está nos Céus, esse é meu irmão, irmã e mãe" (Mt 12,49).

O Mestre toma a defesa das mulheres ao reinterpretar Dt 24,1, onde se fala da carta de divórcio dada pelo marido que despede a esposa "porque viu nela algo de inconveniente". A proibição dessa prática equivale a uma tomada de partido em favor das mulheres que não podem ser objetos nas mãos dos maridos (Mt 5,31-32; 19,3-9).

Ao recolocar em primeiro plano a vontade de Deus, a radicalização de Jesus contesta uma visão patriarcal do divórcio que deu aos maridos a liberdade de se divorciar de suas esposas. A posição de Jesus protege, de fato, os fracos (a esposa de acordo com as representações da época), enquanto a interpretação farisaica do mandamento, embora mais liberal, favorece os poderosos (o marido) (CUVILLIER, 2009, p. 156).

A exceção, "a não ser por motivo de porneía" (Mt 5,32), palavra de difícil tradução, tem a ver com os casamentos ilegítimos, como a união entre parentes de primeiro e segundo graus, previstos em Lv 18,6-18. O tema retorna em Mt 19,1-9, ao se falar do matrimônio no contexto do Reino, onde o marido não tem o direito de se divorciar por qualquer motivo, porque "o que Deus uniu, o homem não deve separar". Por sinal, o trato com qualquer mulher deve ser respeitoso, pois "quem olha para uma mulher com desejo libidinoso já cometeu adultério com ela em seu coração" (Mt 5,28).

As inserções idênticas em ambos os relatos da multiplicação dos pães, "sem contar mulheres e crianças" (Mt 14,21; 15,28), insistem no lugar que as mulheres e as crianças devem ocupar na vida eucarística da comunidade do Reino, que não pode replicar a marginalização vivida no âmbito da vida sinagogal (Mt 5,20).

A cura da sogra de Pedro, diaconisa (diakonéo) do Mestre (Mt 8,14-15), da hemorroíssa, cuja vida se esvaia com o sangue (Mt 9,20-22), e a ressurreição da filha de um chefe (da sinagoga?) (Mt 9,23-26) sinalizam a preocupação 
do Messias com as mulheres marginalizadas. O elogio à mulher cananeia, "mulher, grande é tua fé!" (Mt 15,28), alarga o horizonte e abraça quem não pertence às "ovelhas perdidas da casa de Israel" (Mt 10,6).

No contexto da paixão, as mulheres assumem o protagonismo. A narração inicia-se com a unção em Betânia, quando uma mulher "aproximou-se trazendo um frasco de alabastro com perfume precioso e pôs-se a derramá-lo sobre a cabeça de Jesus", como prenúncio de sua sepultura (Mt 26,7.12). A mulher de Pilatos manda dizer-lhe: "não te envolvas com esse justo, porque muito sofri hoje em sonho por causa dele" (Mt 27,19). Por fim, na contramão dos discípulos medrosos e infiéis, as mulheres seguem o Mestre até o fim. "Estavam ali muitas mulheres, olhando de longe. Haviam acompanhado Jesus desde a Galileia, a servi-lo. Entre elas, Maria Madalena, Maria, mãe de Tiago e de José, e a mãe dos filhos de Zebedeu" (Mt 27,55-56). São elas as primeiras testemunhas da ressurreição, encarregadas de comunicar aos discípulos: "não temais! Ide anunciar a meus irmãos que se dirijam para a Galileia. Lá me verão" (Mt 28,9-10).

\section{6 "Vinde, benditos do meu Pai!" (Mt 25,34)}

Duas perícopes especiais, as bem-aventuranças (Mt 5,1-10) e o juízo final (Mt 25,31-46), contêm um projeto de ethos da comunidade do Reino. A primeira sublinha o modo de proceder característico dos discípulos do Reino. A "pobreza com espírito" recusa todo tipo de idolatria, transubstanciada em injustiça, que leva as pessoas a se comportarem como "deus" na vida do próximo. A mansidão põe fim à violência, pois não responde ao homem mau com a mesma medida (Mt 5,39-42) e pratica o amor aos inimigos (Mt 5,44-47). Experimenta a aflição quem anseia por um mundo melhor, sem ver os ideais se tornarem realidade. A fome e a sede de justiça decorrem da bem-aventurança anterior, e estão presentes na vida dos que vivem o ethos do Reino, embora os fatos contradigam suas expectativas. Misericórdia e pureza de coração são pautas de quem, no trato com o outro, dá tudo de si, com total gratuidade. Os promotores do shalom empenham-se para ver o Reinado de Deus acontecer, o que pode lhes valer perseguição e contrariedade, a serem vividas como bem-aventurança, convictos de fazerem parte de seu projeto de vida.

Na segunda perícope, Mt 25,31-46, a misericórdia e a solidariedade com os mais fragilizados revelam-se ser valores basilares na ética do Reino. Saciar os famintos e os sedentos, acolher os forasteiros, vestir os desnudos, visitar os doentes e os prisioneiros são ações densamente escatológicas, que serão valorizadas no encontro decisivo com o Filho do Homem. Quem escolheu a compaixão como estilo de vida, será acolhido como "bendito do meu Pai", pois, "cada vez que fizestes isto a um desses meus irmãos mais pequeninos, a mim o fizestes". 
Entretanto, muitos discípulos caminham na contramão da misericórdia (Mt 25,41-46), virando as costas para os irmãos carentes (Mt 7,21-23; 22,11-14), quando o ethos do Reino os impulsiona a transformar as palavras em ação, diferente dos que "dizem, mas não fazem" (Mt 23,3).

A parábola dos trabalhadores enviados à vinha ilustra o agir do discípulo do Reino, compassivo com os necessitados de salário para o sustento da família, como os da primeira hora (Mt 20,1-16). A decisão de remunerar a todos igualmente corresponde a uma maneira de "amar a Deus e ao próximo como a si mesmo", mandamento do qual "dependem toda a Lei e os Profetas" (Mt 22,37-40).

\section{7 "Dai a César o que é de César" (Mt 22,21)}

Jesus aproveitou a pergunta sobre o pagamento do tributo devido ao imperador romano para explicitar outro tópico da ética do Reino: a liberdade perante as instituições (Mt 22,15-22). "A liberdade de Jesus, sempre presente em sua vida, é uma das formas de se reconhecer a originalidade de sua pessoa e, assim, a originalidade de seu messianismo", e o de seus discípulos (RIBEIRO, 2009, p. 48).

A questão sobre a liceidade ou não de pagar o imposto a César confrontava Jesus com o Império Romano. Aparentemente, comportava duas alternativas: sim ou não. A resposta "dai a César o que é de César e a Deus o que é de Deus", abre uma terceira possibilidade. O tributo será lícito na condição de negar a César o que não lhe pertence: a adoração devida exclusivamente a Deus.

Nenhuma instituição poderá ser absolutizada! Jesus agiu assim em relação ao Templo (Mt 24,2), ao sábado (Mt 12,8), às tradições religiosas (Mt 15,2), às convenções sociorreligiosas (Mt 8,3), aos laços familiares (Mt 12,46-50), aos preconceitos sociais $(\mathrm{Mt} \mathrm{19,14)}$ e às pretensões de quem detinha o poder religioso (Mt 5,21-48). O absoluto de Deus e a decisão de cumprir sua vontade (Mt 6,10) servem de base para uma sociedade cujos alicerces sejam "a justiça, a misericórdia e a fidelidade" (Mt 23,23; $9,13 ; 12,7)$.

\subsection{Perdoar, de coração, o irmão (Mt 18,35)}

Jesus perdoava pecados (Mt 9,2.6) e exigia dos discípulos a prática do perdão (Mt 18,35). Na oração, devem pedir: "Pai, perdoa-nos as nossas dívidas (opheilémata) como também nós perdoamos aos nossos devedores" (Mt 6,12). São palavras comprometedoras para quem se dispõe a ser tratado na escatologia com os parâmetros usados na história. A metáfora das dívidas alerta para os atritos no trato com o semelhante (Mt 18,21), com a possibilidade de serem superados. 
O perdão e a reconciliação entre os irmãos condicionam a relação com Deus. O culto pressupõe a vida reconciliada. Logo, na eventualidade de as relações com o próximo estarem rompidas, a ordem do Mestre é: "deixa a tua oferta ali diante do altar e vai primeiro reconciliar-te com teu irmão; e depois virás apresentar tua oferta" (Mt 5,23-24). Sem comunhão com o próximo, não será possível a comunhão com Deus.

A transcendência do perdão dado de coração (Mt 18,35; apó tón kardión) provém de sua dimensão teológica. Quem oferece o perdão ao próximo, receberá o perdão de Deus (Mt 6,14-15). O esforço de "ser perfeitos (téleioi) como o Pai celeste é perfeito" (Mt 5,48) move o discípulo do Reino a agir assim, dando passos para alcançar patamares cada vez mais elevados em seu modo de proceder (dikaiosýne), onde o perdão e a reconciliação ocupam lugar privilegiado, atingindo o ápice no amor aos inimigos e na oração pelos perseguidores (Mt 5,44).

\subsection{Deu-lhes exousía para expulsar os espíritos impuros (Mt 10,1)}

A "pureza de coração" (Mt 5,8) pede dos discípulos do Reino atenção para não serem desviados do bom caminho pelos espíritos malignos. Mt 12,43-45 descreve a insistência do "espírito impuro" (akathartón pneúma) em contaminar a vida de quem se tornou discípulo, que se assemelha a uma casa de onde o inimigo de Deus foi expulso. Esse, em sua inquietação, sai em busca de repouso e, não encontrando, decide retornar à sua antiga moradia. E a encontra "desocupada, varrida e arrumada", metáfora do ser humano libertado da ganância, da inveja, do egoísmo, do orgulho, que o colocam na contramão de Deus. O maligno, então, articula um plano perverso: "vai e toma consigo outros sete espíritos piores do que ele e vêm habitar aí", de modo que "a condição final daquele homem se torna pior do que antes".

Os discípulos enviados em missão recebem a exousía de "expulsar espíritos impuros" (Mt 10,1), no sentido de recuperar a bondade, a solidariedade, a misericórdia, o perdão reconciliador no coração humano. Quem abraça a justiça do Reino, por sua parte, pede ao Pai dos Céus que "o livre do Maligno (ponerós)" (Mt 6,13), que está decidido a "arrebatar o que foi semeado em seu coração" (Mt 13,19.38-39).

Os discípulos do Reino mantêm-se em contínua vigilância, por saberem que “do coração procedem más intenções, assassínios, adultérios, prostituições, roubos, falsos testemunhos e difamações" (Mt 15,19), sinais da presença dos espíritos impuros dos quais se devem libertar.

\subsection{0 "Cuidado com o fermento dos fariseus e dos saduceus" (Mt $16,6)$}

A comunidade do Reino tem suas pautas de ação. Todavia, por ser "sal da terra" (Mt 5,13), "luz do mundo" (Mt 5,14) e "fermento" (Mt 13,33), 
está rodeada pelo antirreino que insiste em desviá-la do caminho. Assim sendo, o Mestre alertou os discípulos a estarem atentos quanto ao "fermento dos fariseus e dos saduceus" (Mt 16,6.11), seu "ensinamento (didaché)" (Mt 16,12). Insistiam em elementos secundários, em detrimento do essencial: a justiça, a misericórdia e a fidelidade (Mt 23,23). Uma metáfora ilustra esse desvio de conduta: "coam o mosquito e engolem o camelo" (Mt 23,24). Quanto aos saduceus, por atuarem no espaço do Templo, talvez insistissem no culto e na liturgia, em detrimento da misericórdia (éleos) (Mt 9,13; 12,7).

Os "falsos profetas" atuavam no interior da comunidade, "disfarçados de ovelhas, [quando] por dentro são como lobos ferozes" (Mt 7,15). Tratam-se dos discípulos semelhantes "a sepulcros caiados, que por fora parecem belos, mas por dentro estão cheios de ossos mortos e de toda podridão [...] de hipocrisia e iniquidade" (Mt 23,27-28). O reconhecimento desses indivíduos acontece por seu modo de proceder, contrário ao Reino. A metáfora da árvore e seus frutos serve de ilustração (Mt 7,16-20). Agem como o "inimigo que semeia joio no meio do trigo", pondo em risco a boa semente (M 13,24-25). Assim, a vigilância e o discernimento tornamse exigências, para que o esforço do Messias para construir uma nova humanidade não corra o risco de se perder.

\section{Conclusão}

Uma das muitas vertentes da rica cristologia da catequese mateana apresenta Jesus de Nazaré como Messias, Iesoús Christós, de acordo com as expectativas do judaísmo no século I (Mt 1,1). Sua originalidade consiste em pensá-lo na contramão dos messianismos de então, pelo empenho em fazer nascer a humanidade almejada pelo Pai, radicada na fraternidade, sendo a misericórdia o alicerce das relações interpessoais. Uma leitura de conjunto do evangelho permite desentranhar das entrelinhas os traços da sociedade pela qual lutou, até à morte de cruz. Os discípulos, ao serem constituídos apóstolos, foram enviados em missão com a tarefa de anunciar o Reinado de Deus (Mt 10,2), até os confins do mundo, e fazer novos discípulos (mathetéuo - Mt 28,16-20).

No entanto, o projeto de Jesus de Nazaré foi apropriado pelos organismos eclesiásticos e, com o passar do tempo, tal institucionalização deulhe uma impostação contrária à almejada pelo Mestre. O ethos do Reino cedeu lugar aos dogmas e às doutrinas. $\mathrm{O}$ esforço de criar uma nova humanidade foi substituído pelo proselitismo para fazer aumentar o número dos adeptos das chamadas igrejas cristãs. $\mathrm{O}$ ideal de fraternidade foi atropelado pelas infinitas divisões entre os cristãos. O mundanismo da sociedade avessa ao Reino contaminou a práxis cristã, que convive 
com a injustiça, a desigualdade e a mentira. A pobreza, a fome, o tráfico humano, as migrações forçadas, as hordas de refugiados, as altas taxas de homicídios são banalizações da vida humana em face das quais os cristãos se omitem. O preconceito e a tendência a excluir e marginalizar o semelhante, com frequência, são promovidos por cristãos, bem como o ódio, a violência e as guerras.

Revisitar a catequese mateana recomenda-se para quem está convencido de que vale a pena "buscar o Reino de Deus e sua justiça", nos passos do Messias, Jesus de Nazaré.

\section{Referências}

ALETTI, J.-N. Le Messie souffrant. Un défi pour Matthieu, Marc et Luc. Essai sur la typologie des évangiles synoptiques. Namur; Paris: Editions Jésuites, 2019.

CARVALHO, J. O. Origem e evolução do messianismo em Israel. Didaskalia, Lisboa, v. 30, n. 1, p. 29-51, 2000.

CUVILLIER, E. Torah Observance and Radicalization in the First Gospel. Matthew and First-Century Judaism: A Contribution to the Debate. New Testament Studies, Cambridge, v. 55, n. 2, p. 144-159, apr. 2009.

DÍAZ MATEOS, M. Ustedes todos son Hermanos: la iglesia en San Mateo. Lima: Universidad Ruiz de Montoya; Centro de Estudios y Publicaciones, 2005.

JONES, J. M. Subverting the textuality of Davidic messianism: Matthew's presentation of the genealogy and the Davidic Title. Catholic Biblical Quarterly, Washington, v. 56, n. 2, p. 256-272, apr. 1994.

LOHFINK, G. Jesus de Nazaré: O que Ele queria? Quem Ele era? Petrópolis: Vozes, 2015.

LUZ, U. The Theology of the Gospel of Matthew. Cambridge: Cambridge University Press, 1998.

PAGOLA, J. A. Jesús: aproximación histórica. Madrid: PPC, 2007.

PASALA, S. The "drama" of the Messiah in Mattew 8-9: a study from a communicative perspective. Estudios Biblicos, Madrid, v. 67, n. 3, p. 395-416, jul./set. 2009.

RIBEIRO, A. R. do V. Jesus e os movimentos messiânicos. Revista de Cultura Teológica, São Paulo, v. 17, n. 66, p. 27-54, jan./mar. 2009.

SCARDELAI, D. Jesus e os messianismos de Israel. Estudos Bíblicos, Petrópolis, n. 99, p. 9-22, 2008.

VAN EGMOND, R. The Messianic 'Son of David' in Matthew. Journal of GrecoRoman Christianity and Judaism, Hamilton, v. 3, n. 1, p. 41-71, 2006.

VILJOEN, F. P. Fulfilment in Matthew. Verbum et Ecclesia, Pretoria, v. 28, n. 1, p. 301-324, nov. 2007. 
VITÓRIO, J. Destinatários do kerygma evangélico na perspectiva de Mateus. Revista Eclesiástica Brasileira, Petrópolis, v. 57, n. 226, p. 344-365, 1997.

VITÓRIO, J. Lendo o Evangelho segundo Mateus: o caminho do discipulado do Reino. São Paulo: Paulus, 2019.

VITÓRIO, J. Da Lei de Moisés à justiça do Reino na teologia de Mateus. Vida Pastoral, São Paulo, v. 61, n. 332, p. 30-38, mar./abr. 2020.

Artigo submetido em 30.07.2020 e aprovado em 19.11.2020.

Jaldemir Vitório SJ é Doutor em Teologia Bíblica pela Pontifícia Universidade Católica do Rio de Janeiro (1995). Professor do Departamento de Teologia da Faculdade Jesuíta de Filosofia e Teologia, em Belo Horizonte-MG. Líder do Grupo de Pesquisa A Bíblia em Leitura Cristã. Orcid.org/0000-0002-4655-3167. E-mail: jvitoriosj@faculdadejesuita.edu.br

Endereço: Rua Adelina Sales Pereira, 217

Planalto

31720-440 Belo Horizonte - MG 